\title{
5. SUMMARY OF BIOSTRATIGRAPHY AND MAGNETOSTRATIGRAPHY OF DEEP SEA DRILLING PROJECT LEG 751
}

\author{
John C. Steinmetz, ${ }^{2}$ Eric J. Barron, ${ }^{3}$ Anne Boersma, ${ }^{4}$ Barbara Keating, ${ }^{5}$ Charles McNulty, ${ }^{6}$ \\ Constance Sancetta, ${ }^{7}$ and Herbert Stradner ${ }^{8}$
}

\section{INTRODUCTION}

This chapter summarizes the biostratigraphic and magnetostratigraphic correlations from Leg 75 and highlights some of the problems of cross-correlation between fossil groups and the paleomagnetic record. Various microfossil groups, as well as the macrofossil Inoceramus, were studied and are discussed briefly here. For detailed reports, the interested reader is referred to specific chapters by Barron, Saltzman, and Price for Inoceramus; by Boersma for Pliocene foraminifers; by Keating and Herrero-Bervera for magnetostratigraphy; by McNulty for Cretaceous foraminifers; by Sancetta for Pleistocene and Pliocene diatoms; by Steinmetz and Stradner for Cenozoic calcareous nannofossils; and by Stradner and Steinmetz for Cretaceous calcareous nannofossils.

Leg 75 occupied three sites in the Angola Basin and on the Walvis Ridge in the southeast Atlantic Ocean (Fig. 1). Cenozoic sediments were recovered at all three sites, and Cretaceous sediments were recovered in Hole $530 \mathrm{~A}$. Only two of the eight holes were rotary-cored; the remainder were hydraulic piston cored.

Site 530 is located in the southeastern corner of the Angola Basin in $4629 \mathrm{~m}$ of water. Three holes were drilled at Site 530 . Hole 530 was drilled using a standard rotary coring assembly, but was terminated $(115 \mathrm{~m}$ below seafloor) by technical failure. Hole 530A was drilled to a total depth of $1121 \mathrm{~m}$ using a standard rotary coring assembly. Hole 530B was cored to a depth of $180 \mathrm{~m}$ subbottom using the hydraulic piston coring device.

Site 531 is located in $1267 \mathrm{~m}$ of water on the eastern end of the Walvis Ridge. Two holes were attempted at the site, but in each case the bottom was found to be hard and could not be penetrated. Both cores yielded Holocene foraminiferal ooze.

Site 532 is located in $1331 \mathrm{~m}$ of water on the eastern part of the Walvis Ridge in a trough with relatively thick sediment fill. Site 532 is close to Site 362 drilled on Leg 40. Three holes were hydraulically piston cored. Hole 532 yielded 61 cores reaching a total depth of $250.8 \mathrm{~m}$.

\footnotetext{
${ }^{1}$ Hay, w. W., Sibuet, J.-C., et al., Init. Repts. DSDP, 75: Washington (U.S. Govt. Printing Office).

2 Marathon Oil Company, Denver Research Center, P.O. Box 269, Littleton, Colorado 80160.

${ }^{3}$ National Center for Atmospheric Research, P.O. Box 3000, Boulder, Colorado 80307.

${ }_{5}^{4}$ Microclimates, Box 404 RRI, Stony Point, New York 10980.

5 Hawaii Institute of Geophysics, University of Hawaii, Honolulu, Hawaii.

6 University of Texas at Arlington, Texas.

7 Lamont-Doherty Geological Observatory, Palisades, New York.

8 Geologische Bundesanstalt, Vienna, Austria.
}

Hole 532A, offset about $50 \mathrm{~m}$ to the SSW, yielded 47 cores to a total depth of $199.6 \mathrm{~m}$. This set of cores was sealed unexamined and saved for the JOIDES Sedimentary Petrology and Physical Properties Panel. Hole 532B was offset about $30 \mathrm{~m}$ to the south. Seventy-four cores were taken, reaching a depth of $291.3 \mathrm{~m}$. Control from the rig floor was so exact that Cores 532-61 and 532B-61 correlate within $0.4 \mathrm{~m}$ and can be considered to have been taken at the same level. Hence, coring is continuous from the mudline to the total depth of $291.3 \mathrm{~m}$ in Core 532B-74.

Figures 2 through 5 summarize the biostratigraphic, magnetostratigraphic, and lithologic results from each of the holes studied. Since the calcareous nannofossils provide the most complete coverage of all the holes, and usually provide the highest biostratigraphic resolution here, they are the primary source for age dating of the sediments in this chapter and throughout the volume.

\section{LITHOSTRATIGRAPHY}

Eight sedimentary units and one basalt unit were recognized at Site 530; only one unit was recognized at Site 532 (Table 1). The detailed lithology is discussed elsewhere in this volume, or may be seen in summary form in Hay et al. (1982), from which the following site descriptions have been abstracted.

\section{Site $\mathbf{5 3 0}$}

Unit 1 consists of nannofossil marl and ooze, diatom ooze, and debris-flow deposits. This Holocene to Pleistocene unit is subdivided into three subunits on the basis of relative abundances of diatoms and nannofossils. Subunit 1a consists of Holocene to Pleistocene sediment rich in both diatoms and calcareous microfossils interbedded with debris-flow deposits and diatom-rich mud turbidites. Subunit $1 \mathrm{~b}$ consists of Pleistocene diatomrich, carbonate-poor sediment interbedded with debrisflow deposits.

Unit 2 is composed mainly of Pleistocene to late Miocene calcareous biogenic sediments interbedded with thick debris-flow deposits and thin mud turbidites. The biogenic sediment is composed dominantly of nannofossils, with variable content of foraminifers and clay, and rare siliceous material. The base of Unit 2 coincides with a change in sonic velocity and density of the sediment.

Unit 3 consists of late Miocene to late Oligocene green and red mud, very thin bedded basinal turbidites, pelagic clay, and volcanic-palogonitic silt. Seismic-reflection profiles show that the equivalent of this unit is 


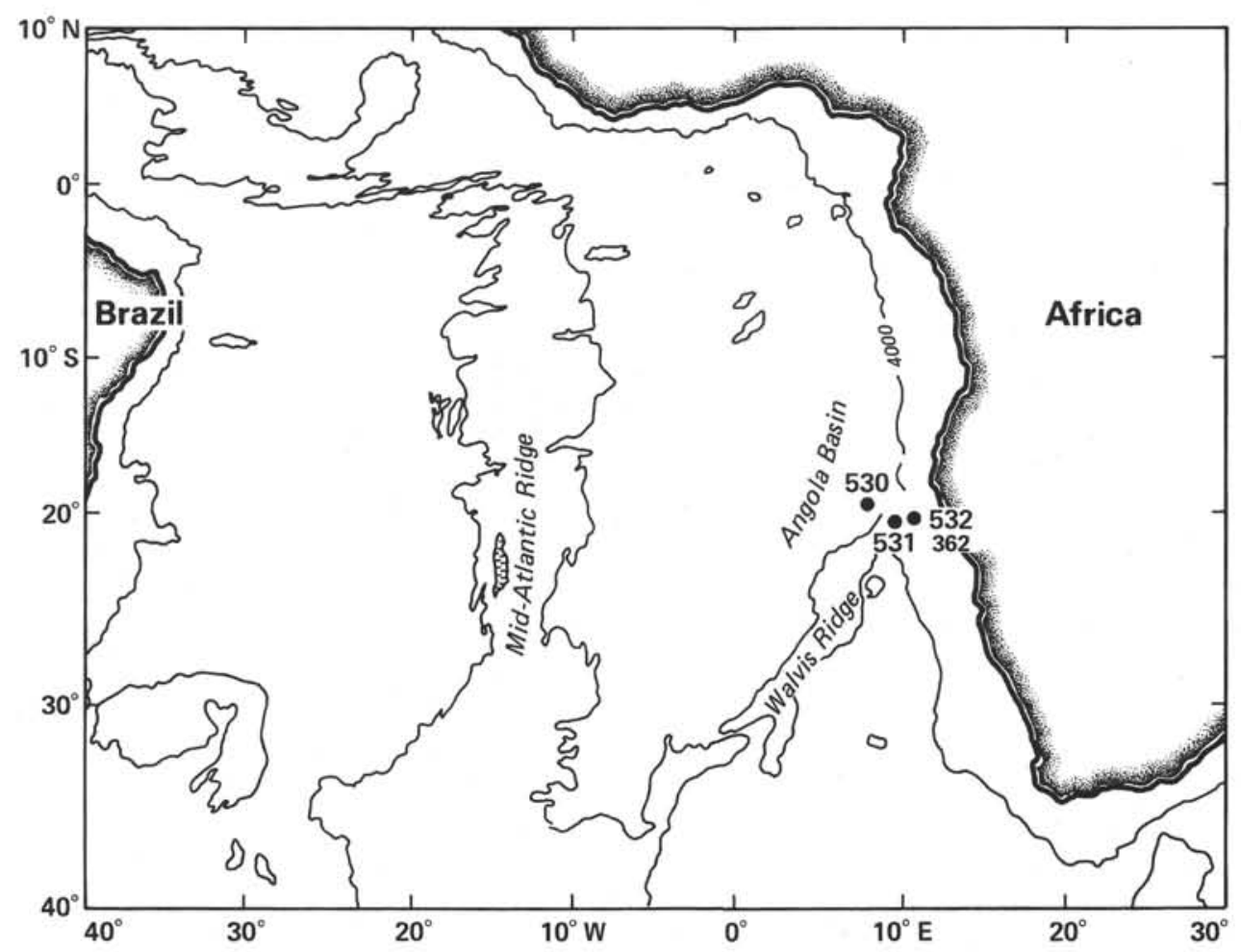

Figure 1. Location map of Leg 75 sites in the Angola Basin and on the Walvis Ridge in the southeastern Atlantic Ocean.

an acoustically transparent layer that extends over much of the Angola Basin and that it is dominated by sediment input from the African continental margin.

Unit 4 consists of late Oligocene to Maestrichtian green mudstone with minor red mudstone, calcareous mudstone, marlstone, and common interbeds of nannofossil chalk and clastic limestone. The colors vary with the proportion of carbonate present. The clastic limestone beds contain mainly shallow-water carbonate debris, including benthic reef foraminifers, shell debris, and fragments of calcareous algae and bryozoa, mixed with volcanic rock fragments, quartz, feldspar, glauconite, and heavy minerals.

Unit 5 consists of Maestrichtian to early Campanian mudstone, marlstone, clastic limestone, and siliciclastic sandstone. Fragments of the large mollusk Inoceramus are present in many of the cores from the Coniacian to the early Maestrichtian. The fragments are usually oriented parallel to stratification and consist of 0.5 to 1.0-cm-thick slabs of fibrous calcite which formed the prismatic layer of the mollusk shell. They often occur as continuous or partly broken layers across the entire width of the core.

Unit 6 consists of early Campanian carbonate-cemented greenish-black volcanogenic sandstones. The sandstones occur as thin $(5-10 \mathrm{~cm})$ to thick $(1-3 \mathrm{~m})$ graded turbidites that show partial or complete Bouma sequences.

Unit 7 is early Campanian to Santonian, predominantly red claystone with interbeds of green, red, and purple siltstone and claystone and green sandstone in numerous repeated turbidite sequences. The green beds are the result of reduction in iron in the red claystone, usually on either side of a thin silt lamina or layer.

Unit 8, the basal sedimentary unit, is Santonian to late Albian, predominantly red and green claystone with beds of black shale. A total of 260 individual black shale beds were recognized within $160 \mathrm{~m}$ of the $163-\mathrm{m}$ thick stratigraphic section. The average thickness of the black shale beds is $4.3 \mathrm{~cm}$ (range of 1 to $62 \mathrm{~cm}$ ), and the average organic carbon content is $5.7 \%$ (range $1.4 \%$ to $18 \%$ ).

Unit 9 is a medium-gray, fine-grained basalt containing veins and vugs filled with calcite.

\section{Site $\mathbf{5 3 2}$}

Subunit 1a consists of Pleistocene nannofossil foram ooze and nannofossil ooze. It is frequently diatomaceous, bioturbated, and organic-rich. It ranges in color from a light olive gray to a moderate olive brown. Subunit $1 \mathrm{~b}$ consists of Pleistocene and Pliocene, completely bioturbated diatom nannofossil marl and sarl (see Explanatory Notes for definition), and diatom nannofossil ooze. It ranges in color from olive brown to light olive gray. Subunit 1c is a Pliocene to late Miocene, foramrich, bioturbated, diatomaceous nannofossil marl which is yellowish light olive gray in color.

\section{CENOZOIC CALCAREOUS NANNOFOSSILS}

Cenozoic calcareous nannofossils were recovered from sediments at all three sites occupied on DSDP Leg 75. The youngest sediment recovered is Holocene from the Emiliania huxleyi Zone, and the oldest sediment is at the Cretaceous/Tertiary boundary in Hole 530A. The 


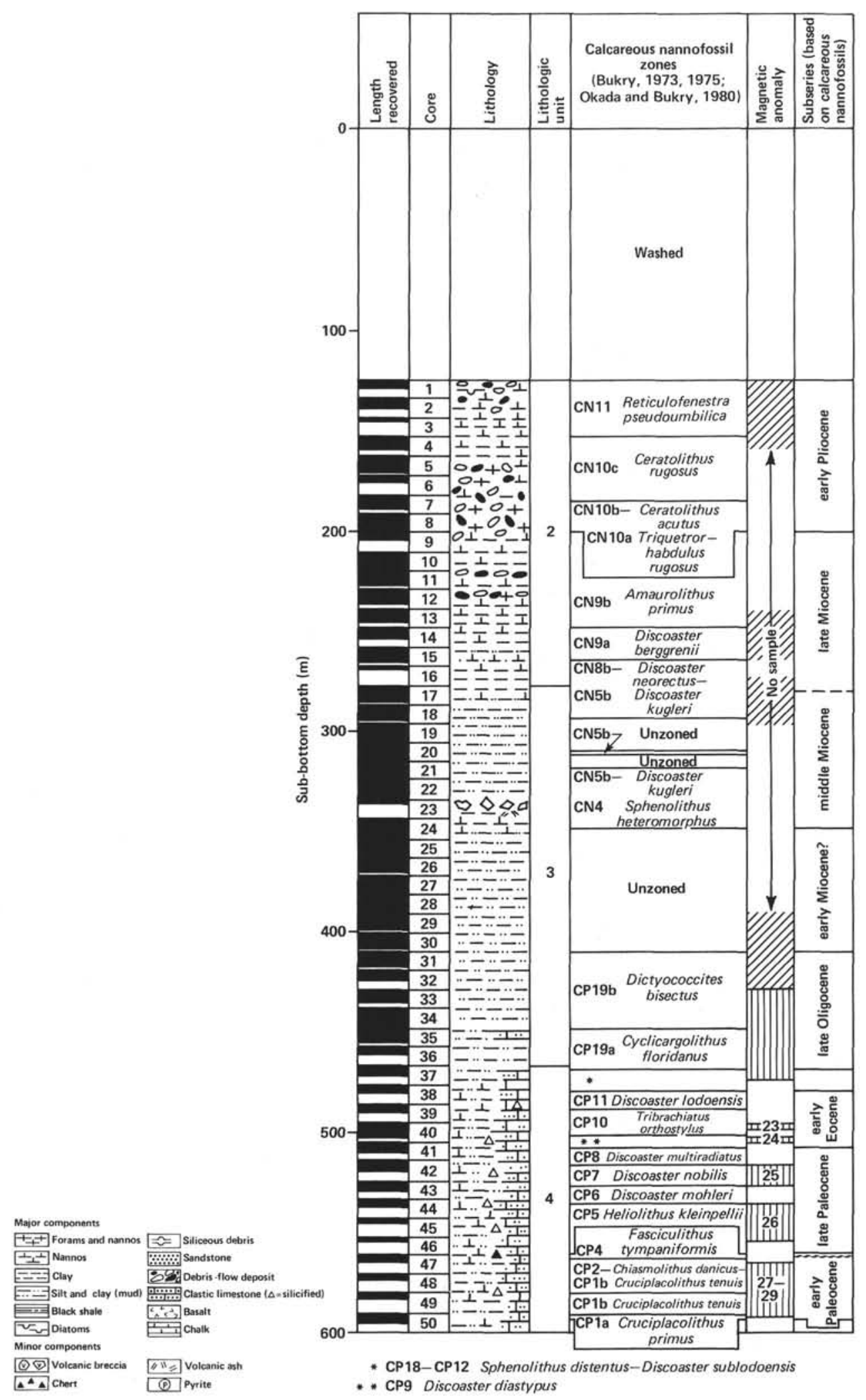

Figure 2. Lithologic, biostratigraphic, and magnetostratigraphic summary, Hole 530A (Cenozoic section). Within the magnetic anomaly column, dark represents normal polarity and white represents reversed polarity. 


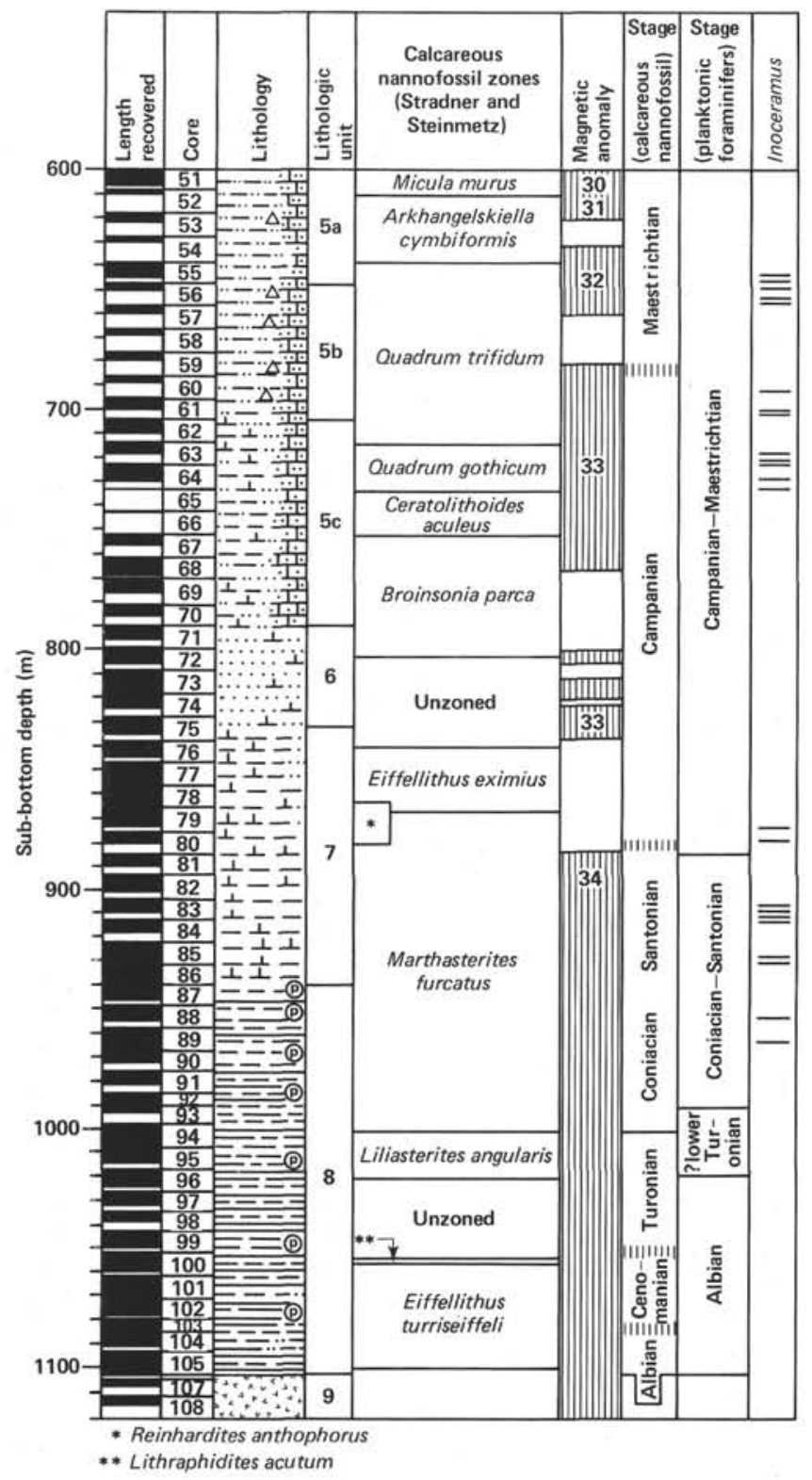

Figure 3. Lithologic, biostratigraphic, and magnetostratigraphic summary, Hole 530A (Cretaceous section). Within the magnetic anomaly column, dark represents normal polarity and white represents reversed polarity. (See Fig. 2 for key to graphic lithology symbols.)

nannofossils are generally common to abundant and moderately well preserved, where present. Species assemblages are relatively diverse, permitting the use of low-latitude zonations for biostratigraphy. Steinmetz and Stradner (this volume) studied the Cenozoic nannofossils from each core catcher retrieved and from several samples in each core where it was deemed appropriate. They reported their results using three zonations currently in use: the Standard Nannoplankton Zonation of Martini (1971), and the zonations of Bukry (Bukry, 1973, 1975; Okada and Bukry, 1980) and of Ellis (1979, 1982). Results reported here utilize the zonation of Bukry with its modifications.

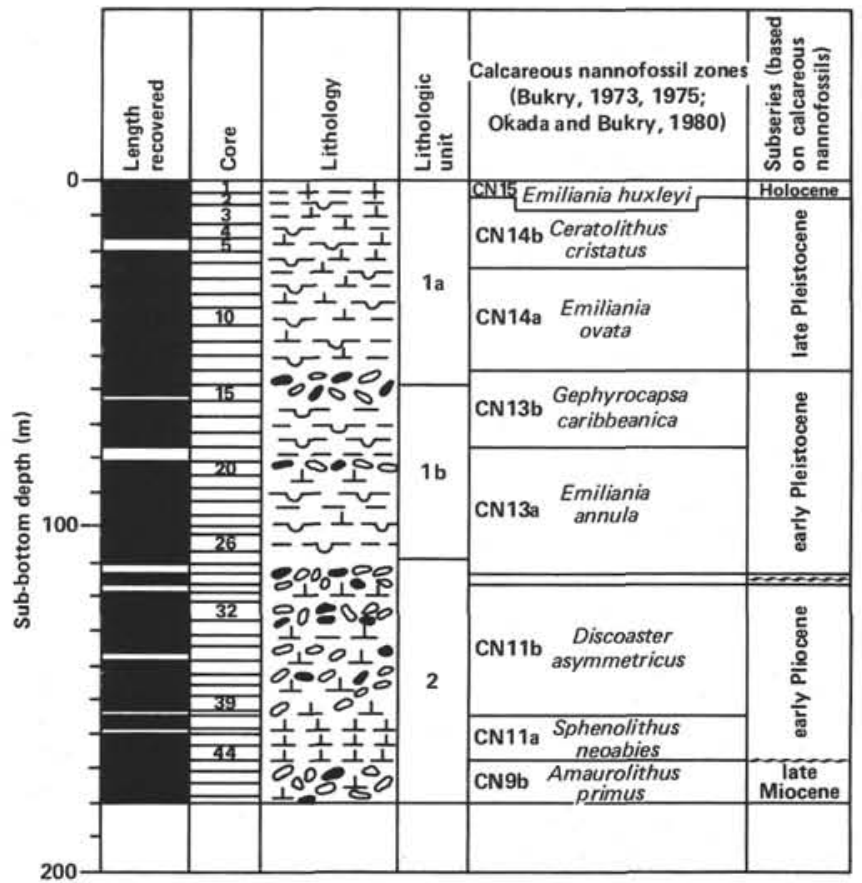

Figure 4. Lithologic and biostratigraphic summary, Hole 530B. (See Fig. 2 for key to graphic lithology symbols.)

\section{Holocene}

The Holocene Emiliania huxleyi Zone (CN 15), determined by the presence of the nominate species, was found at all three sites in Holes 530, 530B, 531, 531A, and 532 .

\section{Pleistocene}

Bukry has divided the Pleistocene into four subzones, two each in the early and the late Pleistocene. In two holes (530B and 532) where the Pleistocene was not washed, all four subzones are present and separable. The late Pleistocene Emiliania ovata and Ceratolithus cristatus Subzones (CN 14a and CN 14b) lie entirely within lithologic Unit 1a. Lithologic Unit 1b encompasses the early Pleistocene Emiliania annula and $\mathrm{Ge}$ phyrocapsa caribbeanica Subzones (CN 13a and CN $13 \mathrm{~b})$ and the upper half of the Late Pliocene Discoaster brouweri Zone (CN 12a to $\mathrm{CN} \mathrm{12d).}$

\section{Pliocene}

The entire Pliocene is present in Holes 532 and 532B, but because of slumping, not all of Bukry's nine subzones are separable. The Pliocene is also present at Site 530, but the entire late Pliocene Discoaster brouweri Zone (CN 12a to $\mathrm{CN} \mathrm{12d)} \mathrm{is} \mathrm{missing.} \mathrm{As} \mathrm{a} \mathrm{result,} \mathrm{the}$ early Pleistocene rests unconformably on the early Pliocene at Site 530. Lithologic Unit 1c ranges from early late Pliocene to late late Miocene at Site 532. It is not present, or distinguished, at Site 530. Instead, lithologic Unit 2 ranges from the early Pliocene through the entire late Miocene at Site 530. 


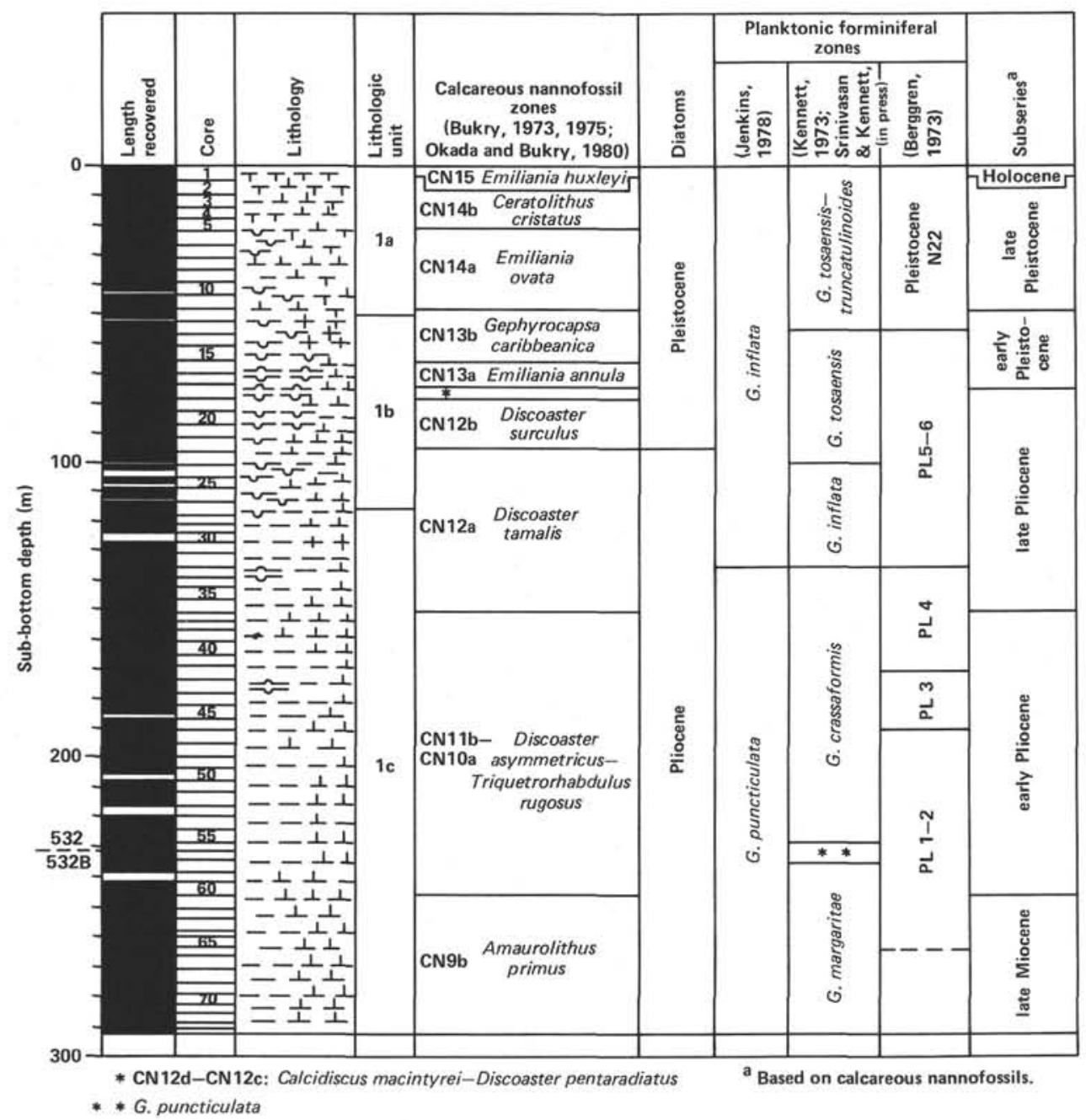

Figure 5. Lithologic and biostratigraphic summary, Holes 532/532B. (See Fig. 2 for key to graphic lithology symbols.)

\section{Miocene}

Miocene sediments were recovered at Sites 530 and 532. Holes 530B and 532B bottomed in the uppermost late Miocene Amaurolithus primus Subzone (CN 9b). Recovery in Hole 530A was good throughout the Miocene section; however, much of the middle and perhaps all of the early Miocene are barren of calcareous nannofossils. Lithologic Unit 2 extends through the late Miocene. Lithologic Unit 3 includes the middle Miocene down through the late Oligocene.

\section{Oligocene}

Oligocene and older sediments were only drilled on Leg 75 in Hole 530A. Only.late Oligocene subzones CP 19a and CP 19b of the Sphenolithus ciperoensis Zone are clearly detectable. The remainder of the Oligocene occurs in an extremely compressed section in Core 37, where taxa from the middle Oligocene down through the middle Eocene are found, Sphenolithus distentus Zone to Discoaster sublodoensis Zone (CP 18 to CP 12). Lithologic Unit 3 extends downward from the Miocene through the late Oligocene. Lithologic Unit 4 extends down from the middle Oligocene to the basal Cenozoic sediments in Core 50.

\section{Eocene}

The entire Eocene section is also greatly compressed. From Core 37 to Core 41,7 zones or subzones are detectable (Bukry has 13 subzones in the Eocene). Part of the middle-late Eocene is missing entirely.

\section{Paleocene}

Except for the Ellipsolithus macellus Zone (CP 3), the Paleocene is very well represented. From Core 41-1 to Core 50-2, seven zones or subzones (compared to Bukry's 10) are distinguishable.

\section{Cretaceous/Tertiary Boundary}

The Cretaceous/Tertiary boundary is well documented, with some Cretaceous mixing into Tertiary sediments (see Steinmetz and Stradner, and Stradner and Steinmetz, this volume). The boundary lies in Core 50 at about $592.5 \mathrm{~m}$ sub-bottom. Traces of burrowing organisms can clearly be seen, and therefore a precise contact level cannot be observed. The exact layer of the 
Table 1. Composition, cores, and depth of occurrence, thickness, and age of lithologic units at Site 530 (southern Angola Basin) and Site 532 (eastern Walvis Ridge).

\begin{tabular}{|c|c|c|c|c|c|}
\hline Unit & Lithology & Hole, Core & $\begin{array}{l}\text { Sub-bottom } \\
\text { depth }(m)\end{array}$ & $\begin{array}{l}\text { Thickness } \\
\text { (m) }\end{array}$ & Age \\
\hline la & $\begin{array}{l}\text { Diatom nannofossil marl and ooze } \\
\text { and debris-flow deposits }\end{array}$ & $530 \mathrm{~B}, 1-14$ & $0.0-58.0$ & 58.0 & $\begin{array}{l}\text { Holocene to early } \\
\text { Pleistocene }\end{array}$ \\
\hline $1 \mathrm{~b}$ & $\begin{array}{l}\text { Diatom ooze and debris-flow de- } \\
\text { posits }\end{array}$ & $530 \mathrm{~B}, 15-27$ & $58.0-110.0$ & 52.0 & early Pleistocene \\
\hline 2 & $\begin{array}{l}\text { Nannofossil clay, marl, and ooze } \\
\text { and debris-flow deposits }\end{array}$ & $\begin{array}{l}\text { 530B, 28-48; 530A, } \\
1-16\end{array}$ & $110.0-277.0$ & 167.0 & $\begin{array}{l}\text { early Pleistocene to } \\
\text { late Miocene }\end{array}$ \\
\hline 3 & Red and green mud & $530 \mathrm{~A}, 17-36$ & $277.0-467.0$ & 190.0 & $\begin{array}{l}\text { late Miocene to } \\
\text { late Oligocene }\end{array}$ \\
\hline 4 & $\begin{array}{l}\text { Multicolored mudstone, marlstone, } \\
\text { chalk, and clastic limestone }\end{array}$ & $530 \mathrm{~A}, 37-50$ & $467.0-600.0$ & 133.5 & $\begin{array}{l}\text { late Oligocene to } \\
\text { Maestrichtian }\end{array}$ \\
\hline $5 a$ & $\begin{array}{l}\text { Dark green mudstone, marlstone } \\
\text { and clastic limestone }\end{array}$ & $530 \mathrm{~A}, 50-55$ & $600.0-647.5$ & 47.5 & Maestrichtian \\
\hline $5 b$ & $\begin{array}{l}\text { Dark green mudstone, maristone, } \\
\text { clastic limestone, and siliciclas- } \\
\text { tic sandstone }\end{array}$ & $530 \mathrm{~A}, 56-61$ & $647.5-704.5$ & 57.0 & $\begin{array}{l}\text { Maestrichtian to } \\
\text { late Campanian }\end{array}$ \\
\hline $5 \mathrm{c}$ & $\begin{array}{l}\text { Dark green mudstone, marlstone, } \\
\text { and calcareous siliciclastic } \\
\text { sandstone }\end{array}$ & $530 \mathrm{~A}, 62-70$ & $704.5-790.0$ & 85.5 & $\begin{array}{l}\text { middle to late } \\
\text { Campanian }\end{array}$ \\
\hline 6 & Glauconitic sandstone & $\begin{array}{l}\text { 530A, } 71-75 \\
\text { (Sections } 1 \text { and } 2 \text { ) }\end{array}$ & $790.0-831.0$ & 41.0 & early Campanian \\
\hline 7 & $\begin{array}{l}\text { Variegated red and green clay- } \\
\text { stone, siltstone, and sandstone }\end{array}$ & $\begin{array}{l}\text { 530A, } 75 \\
\text { (Section 3)-86 }\end{array}$ & $831.0-940.0$ & 109.0 & $\begin{array}{l}\text { early Campanian } \\
\text { to Coniacian }\end{array}$ \\
\hline 8 & $\begin{array}{l}\text { Red and green claystone and marl- } \\
\text { stone with interbedded black } \\
\text { shale }\end{array}$ & $530 \mathrm{~A}, 87-105$ & $940.0-1103.0$ & 163.0 & $\begin{array}{l}\text { Coniacian to } \\
\text { Albian }\end{array}$ \\
\hline 9 & Basalt & $530 \mathrm{~A}, 105, \mathrm{CC}-108$ & $1103.0-1121.0$ & 19.0 & \\
\hline 1a & Nannofossil foram ooze & $532,1-12$ & $0.0-52.4$ & 52.4 & $\begin{array}{l}\text { Holocene to early } \\
\text { Pleistocene }\end{array}$ \\
\hline $\mathrm{lb}$ & Diatom nannofossil marl & $\begin{array}{l}532,13-27 \\
\text { (Section 2) }\end{array}$ & $52.4-116.2$ & 53.8 & $\begin{array}{l}\text { early Pleistocene to } \\
\text { late Pliocene }\end{array}$ \\
\hline ic & Nannofossil marl & $\begin{array}{l}\text { 532, } 27 \\
\quad \text { (Section 2)-61 } \\
\text { 532B, 27-73 }\end{array}$ & $116.2-291.3$ & 175.1 & $\begin{array}{l}\text { late Pliocene to } \\
\text { late Miocene }\end{array}$ \\
\hline
\end{tabular}

$\mathrm{C} / \mathrm{T}$ boundary is not shown. Within $150 \mathrm{~cm}$ from the first occurrence of Biantholithus sparsus in an otherwise strictly Maestrichtian nannoflora up to the first typical Danian assemblage with only minor Maestrichtian admixture, there is much alternation of some poorly, some better preserved samples, and a transitional replacement of Maestrichtian taxa by the newly evolving Tertiary ones.

\section{CRETACEOUS CALCAREOUS NANNOFOSSILS}

Stradner and Steinmetz (this volume) studied the only Cretaceous calcareous nannofossils recovered on Leg 75 in Hole 530A. For zonal definitions, Pflaumann and Cepek (1982) were widely followed. One new nannofossil zone, the Liliasterites angularis Zone, and three new species, Liliasterites angularis, L. atlanticus, and Micula swastica, are described. The sequence from late Maestrichtian to late Albian is divided into 13 nannofossil zones. The nannofossil horizons marked by the first and last occurrences of the guide species are correlated with the position of the paleomagnetic anomalies (Keating and Herrero-Bervera, this volume) and the absolute timespan covered by each nannofossil zone is discussed.

\section{Maestrichtian}

Two zones, Micula murus Zone and Arkhangelskiella cymbiformis Zone, as well as the upper half of the Quadrum trifidum Zone are detectable in the Maestrichtian. These encompass all of lithologic Unit $5 \mathrm{a}$ and half of Unit $5 \mathrm{~b}$, which extends down into the Campanian. Magnetic anomalies 30 and 31, occurring together, and 32 , are recorded in the sediment.

\section{Campanian}

Except for most of lithologic Unit 6 which remains unzoned, the Campanian includes half of lithologic Unit $5 \mathrm{~b}$, all of $5 \mathrm{c}$, and the upper half of Unit 7. Five nannofossil zones are resolved in the Campanian, as well as the Quadrum trifidum Zone, which spans the Campanian-Maestrichtian boundary. The Campanian/ Maestrichtian boundary can be defined on the basis of the paleomagnetic record. Based upon comparisons with other Atlantic DSDP cores, the boundary should occur at the transition from normal to reversed polarity (past Anomaly 33), at the top of Core 60 .

\section{Santonian-Coniacian}

The Santonian and Coniacian are not well represented from Cores 81 to 93 , and the entire interval is assigned to the Marthasterites furcatus Zone. Magnetic anomaly 34 , which constitutes the magnetic quiet zone, extends from the top of this section at Core 81 down to the bottom of the hole at Core 108. The sequence encompasses the lower half of lithologic Unit 7 and the upper half of Unit 8.

\section{Turonian-Cenomanian-Albian}

This sequence, from Core 94 to 105 , is poorly represented, is poorly zoned as a result of the lack of useful biostratigraphic markers, and includes only three zones which are detectable: Liliasterites angularis Zone (Turonian), Lithraphidites acutum Zone (Cenomanian), and the Eiffellithus turriseiffeli Zone (Cenomanian-Albian). 


\section{PLIOCENE FORAMINIFERS}

Boersma studied the Pliocene planktonic and benthic foraminifers from Leg 75, Holes 532 and 532B (this volume). The $149 \mu \mathrm{m}$ fraction from Hole 532, Cores 12 to $61(48.0$ to $250.8 \mathrm{~m}$ ) (core catchers and an occasional extra sample) and from Hole 532B, Cores 12 to 71 (47.4 to $285.3 \mathrm{~m}$ ) (core catchers only) were examined. The characteristic Pliocene low-latitude biostratigraphic indices Globorotalia multicamerata, G. miocenica, Sphaeroidinellopsis seminulina-subdehiscens, Globoquadrina altispira, and Globigerina nepenthes were found only sporadically and in low abundance. A rough subdivision of the Pliocene according to Berggren (1973) is possible. It is not possible to separate Zones Pl 1-2 and Pl 5-6 because of the simultaneous disappearance of $G$. nepenthes and Globorotalia magaritae in the former case, and the absence of $G$. miocenica above Zone Pl 4.

The Pliocene zones of Jenkins (1978) and of Kennett (1973) and Srinivasan and Kennett (in press, 1982) were easily recognized by the presence/absence of the nominate species. The Globorotalia puncticulata Zone is particularly short because of the appearance of $G$. crassaformis almost immediately above that of $G$. puncticulata.

Comparison of foraminiferal and nannofossil stratigraphy (Steinmetz and Stradner, this volume) demonstrates offsets between respective zones or subseries. Boersma suggests that these offsets are due to solutionsusceptible foraminiferal indices displaced by the intense dissolution of the mid-Pliocene, or to ecologically induced delay in appearance related to upwelling.

Benthic foraminifers were studied in the $64 \mu \mathrm{m}$ fraction from core catchers in Cores 10 to 61 in Hole 532 and Cores 10 to 71 in Hole 532B. Faunas are dominated by long-ranging geographically widespread species. Several species are indicative of the shallow depth $(1331 \mathrm{~m})$ and continental slope location of the site. Benthic abundance correlates with the preservation of planktonic foraminifers. Benthic diversity varies from a low of 8 species in a rich planktonic ooze (Sample 532-42-3, $58 \mathrm{~cm}$ ) to highs of 32 species in Cores 54 to 58 and near 30 species in poorly preserved samples of late Pliocene Cores 24 to 28 . Through the Pliocene section of Site 532 , five ecologically controlled faunal episodes could be recognized.

\section{CRETACEOUS FORAMINIFERS}

McNulty studied the Cretaceous foraminifers from Leg 75 , Hole 530A. The recovery of foraminifers was poor. Three-quarters of all washed $\left(10 \mathrm{~cm}^{3}\right.$ volume) residues yielded few or no specimens. The majority of the residues containing sufficient numbers of foraminiferal specimens ( $1 \%$ or more) have populations that are totally or dominantly benthic, except from Cores 79,88 , and 94 . The majority of the total benthic fauna are not recurrent-that is, most benthic species occur in one or two samples only. In addition to the scarcity of taxa and the lack of persistent species, the foraminiferal populations are characterized by conspicuously poor preservation.
Because of the rarity of planktonic species, established planktonic foraminiferal biozones could not be recognized. The chronostratigraphic intervals employed are based on both the few, rare, and erratic planktonic species and a small number of long-ranging recurrent benthonic species.

\section{Maestrichtian-Campanian}

This interval extends from Core 50, Section 2 to Core $80, \mathrm{CC}(592.0$ to $885.0 \mathrm{~m})$. The Tertiary/Cretaceous boundary is not well documented by foraminifers. The base of the interval is determined on very poorly preserved, rare, and infrequent globotruncanids and a restricted but relatively persistent Paleogene to Campanian benthic assemblage. The volcanogenic interval of Core 71 to 75 (lithologic Unit 6, 790.0 to $837.5 \mathrm{~m}$ ) yielded no planktonic foraminifers. The interval of Core 76 to 80 (upper lithologic Unit 7, 837.5 to $885.0 \mathrm{~m}$ ) provided more planktonic species than did any other interval of the hole and provides this interval with the best correlation in the hole (lower Campanian). The fauna is distinguished by simple and early globotruncanids, such as Globotruncana arca, G. fornicata, G. linneiana, and $G$. ventricosa, by terminal marginotruncanids, including Marginotruncana asymmetrica and $M$. sinuosa, by Planoglobulina glabretta, and by rare, infrequent, other species.

\section{Santonian-Coniacian}

This interval extends from Cores 81 through 92 $(885.0$ to $990.0 \mathrm{~m})$. The upper part (Core 81 through 86 , 885.0 to $940.0 \mathrm{~m}$ ) is composed of red and green claystones and vari-colored turbiditic siltstones and sandstones which yielded a sparse fauna of quartzose, agglutinated species. Within this interval, the benthic fauna changes from upper to lower Senonian forms. Planktonic species are rare and poorly preserved, except for one sample from $86-3,47-49 \mathrm{~cm}(934.5 \mathrm{~m})$. The lower part of this interval (Cores 87 through $92,940.0$ to $990.0 \mathrm{~m}$ ) is marked by black shales among the variegated clastics. Planktonic specimens are common in black shale samples from 88-3, 120-122 cm and 92,CC ( $953.2 \mathrm{~m}$ and $990.0 \mathrm{~m}$, respectively), but they are absent or very rare in other lithofacies. Benthic agglutinated forms are present in the red and green claystones, and other benthic species are abundant in some of the light gray, thin, turbiditic beds.

The Santonian-Coniacian age is indicated by the marginotruncanids, particularly Dicarinella concavata, by the sparse but persistent Hedbergella flandrini, and by three of the rare but persistent benthics, namely Aragonia materna kugleri, Osangularia popenoei, and Spiroplectammina chicoana.

\section{?lower Turonian}

The faunas in the 30 -m interval from Cores 93 through 95 (990.0 to $1017.0 \mathrm{~m}$ ) are marked by a mixing of upper and lower Cretaceous forms. Most of the planktonics and some of the benthics are lower Turonian or younger; the balance are typical of, if not limited to, the Albian. Distorted bicarinate globotruncaniform and 
spinose, nodose, to partially costellate hedbergelliform planktonic species are common to abundant in some black shales, but are rare to absent in the turbidites or claystones. Prominent representatives of the globotruncaniforms are Dicarinella canaliculata, D. imbricata, Marginotruncana pseudolinneiana, and $M$. coronata. Typical hedbergellids are Hedbergella delrioensis, $H$. hoezli, $H$. planispira, and $H$. simplex. The prominent ol persistent benthic species include Dorothia filiformis, Gavelinella berthelini, G. umbonella, Gyroidina quadrata, ?Conorbina newtoni, Pseudoclavulina gaultina, and Spiroplectammina chicoana.

\section{Albian}

This interval extends from Cores 96 through 105 $(1017.0$ to $1103.0 \mathrm{~m})$ and is characterized by silica-filled radiolarian tests. Where they are common, in the greenish-gray siltstones and black claystones, foraminifers are typically rare or absent. A sparse, narrow fauna of primitive quartzose, agglutinated foraminifers occurs in the red and green claystones of the interval. Most specimens are badly deformed, limiting identification largely to the generic level. The most conspicuous taxa of the interval are relatively large and frequent, smoothly finished calcitic agglutinated forms from gray siltstones, namely Ammosphaeroidina sp., Arenobulimina sp., Dorothia gradata, and Pseudoclavulina gaultina carinata. Planktonic specimens are absent to rare in all but one sample $(104-2,49-52 \mathrm{~cm} ; 1087.0 \mathrm{~m})$, in which about $25 \%$ of the population is composed of small hedbergellids, including Hedbergella infracretacea, $H$. libyca, $H$. planispira, and $H$. simplex.

\section{DIATOMS}

Sediments from Leg 75 containing diatoms were studied by Sancetta (this volume). Most of the stratigraphic section does not contain any diatoms. The Pliocene and Pleistocene intervals which are diatomaceous usually lack the tropical and high-latitude marker species necessary for biostratigraphy. These intervals are completely dominated by forms adapted to the unusual upwelling conditions.

The stratigraphic markers which are present have been recognized in the Pacific Ocean by Burckle (1977) and Koizumi (1977). There, the species events have been correlated with the paleomagnetic record. Sancetta interpreted the biostratigraphy using Pacific Ocean species ranges, and she cautions that since the ranges of these species have not been adequately confirmed in the Atlantic Ocean, the absolute ages may be different.

\section{Site $\mathbf{5 3 0}$}

Only Units $1 \mathrm{a}$ and $1 \mathrm{~b}$ of Hole 530B contain significant numbers of diatoms (Cores 1-27; 0-110 m). Pseudoeunotia doliolus, which ranges through the Pleistocene in the Pacific, is sporadically present throughout this interval. The top of Nitzschia reinholdii occurs in $10, \mathrm{CC}(41 \mathrm{~m})$. The extinction of $N$. reinholdii in the tropical Pacific occurs in the lowermost Brunhes (Burckle, 1977) or uppermost Matuyama (Sancetta, 1982).
In Hole 530B, this datum occurs within or between debris flows, suggesting to Sancetta that the datum may be displaced. Calcareous nannofossil biostratigraphy (Steinmetz and Stradner, this volume) of 10,CC indicates that it is in the middle of the Emiliania ovata Subzone (CN 19a) (Bukry, 1973, 1975; Okada and Bukry, 1980), correlative with the lower boundary of the Brunhes (Barron et al., 1981).

The Jaramillo, marked in the Pacific by the acme of Mesocena quadrangula, was not detected in any samples. This may have been obscured by debris flows. This short-lived event is correlative with the base of the Emiliania ovata Subzone (Barron et al., 1981), i.e., the lowest occurrence of Gephyrocapsa oceanica. This occurs between $13, \mathrm{CC}$ and $14, \mathrm{CC}(54.2$ to $58.2 \mathrm{~m})$.

The top of Rhizosolenia barboi occurs in 21,CC $(88.0 \mathrm{~m})$ in the early Pleistocene. Koizumi (1977) locates it above the Olduvai event in the mid-Matuyama.

The sediments below Core 27 are essentially devoid of diatoms. As a result, Sancetta could only say that the Plio/Pleistocene boundary must be below Core 27. Calcareous nannofossils show the boundary to be between $28, \mathrm{CC}$ and $29, \mathrm{CC}$ (113.2 to $116.2 \mathrm{~m}$ ) (Steinmetz and Stradner, this volume).

\section{Site $\mathbf{5 3 2}$}

Diatomaceous sediments are only present between Cores 6 and 27 (21.6 to $117.4 \mathrm{~m}$ ), and are only common from Cores 9 to 20 ( 34.8 to $87.6 \mathrm{~m}$ ). Abundance and preservation of diatoms within this interval are variable, depending on the proportions of calcium carbonate and clay present.

The Pleistocene marker Pseudoeunotia doliolus is not often present and its range is unreliable. The top of the Nitzschia reinholdii range occurs in $6, C C(26.0 \mathrm{~m})$, but since this is the upper limit of diatoms in the section, this event is probably not age-diagnostic. Similarly, Mesocena quadrangula occurs from 6,CC to 8,CC (26.0 to $34.8 \mathrm{~m}$ ). In the Pacific, its acme ranges across the Jaramillo.

In Sample 532-9-1, $100 \mathrm{~cm}$ (35.8 m), a few specimens of Rhizosolenia matuyamai occur. This species ranges just below the Jaramillo in the North Pacific (Burckle et al., 1978). The top of $R$. barboi (mid-Olduvai?) occurs in $13, \mathrm{CC}(56.8 \mathrm{~m})$.

The only occurrence of $R$. praebergonii occurs in $22, \mathrm{CC}(96.4 \mathrm{~m})$. In the equatorial Pacific, its extinction occurs at the top of the Olduvai, correlative with the Plio/Pleistocene boundary. Steinmetz and Stradner (this volume) place the Plio/Pleistocene boundary, based on nannofossils, at 17,CC (74.4 m), $22 \mathrm{~m}$ shallower. Sancetta suggests that this discrepancy is the result of (1) displaced discoasters, (2) a shorter range for $R$. praebergonii in the Atlantic than in the Pacific, or (3) the fact that the species may have undergone an ecologic exclusion in this upwelling regime.

Thalassiosira convexa occurs in Core 26 , the lowest sample in which diatoms are common. In the Pacific, the extinction of T. convexa is in the lower Matuyama (Burckle, 1977). 


\section{INOCERAMUS}

Barron, Saltzman, and Price (this volume) investigated the occurrence of Inoceramus in the South Atlantic. Abundant Inoceramus, ranging in age from Maestrichtian to the Coniacian, are present in Hole 530A. The Inoceramus occurrences in the South Atlantic represent a wide range of paleodepths. A comparison of the occurrence of Inoceramus with the sedimentology indicates that Inoceramus is rare in sediments which have been characterized by down slope transport. The paleodepth of Inoceramus in Hole 530A during the Late Cretaceous is in the range of 3500 to $4500 \mathrm{~m}$, based on the basement age of a standard thermal subsidence history. This evidence is indicative of a greater depth range than previously suggested by Thiede and Dinkelman (1977). Paleodepths as shallow as 100 to $400 \mathrm{~m}$ in the early Campanian at Site 21 were suggested by Maxwell et al. (1970). Hence, it does not appear that Inoceramus is indicative of any specific paleodepth.

Because Inoceramus preserved in the deep sea is not subject to the more variable environmental conditions occurring in epicontinental seas, they may accurately record bottom-water temperatures during the Cretaceous. Stable isotope measurements obtained from well-preserved specimens in Hole 530A suggest bottom-water temperatures in the Angola Basin decreased from $23^{\circ} \mathrm{C}$ during the Coniacian to $13^{\circ} \mathrm{C}$ near the end of the Campanian.

The relatively warm bottom-water temperature for the Coniacian is stratigraphically associated with the deposition of black shales. During much of the Cretaceous, the African margin of the Angola Basin was characterized by extensive epicontinental seas which probably experienced relatively high evaporation rates in the subtropical latitudes (Barron et al., 1981; Barron and Harrison, 1981). Warm temperatures and high salinity, and hence low oxygen solubility (Weiss, 1970), are likely to promote anoxia. Mixing of cool and warm sources probably increased toward the end of the Cretaceous. Differences between sedimentary regimes in the Angola Basin, as compared to the Brazil Basin, support the hypothesis that the evolution of oceanic circulation in the South Atlantic was controlled by the tectonic setting, paleolatitudes, and the distribution of epicontinental seas.

\section{MAGNETOSTRATIGRAPHY}

Keating and Herrero-Bervera studied the magnetostratigraphy of early Cenozoic and Cretaceous sediments from Site 530 in the Angola Basin (this volume). Approximately 500 samples were collected from Cores 35 through 108 (lithologic Units 3 through 9), using a sampling interval of approximately $35 \mathrm{~cm}$ within the Cretaceous cores. A sequence of geomagnetic reversals were recorded in the Oligocene to late Albian sediments which correspond to seafloor magnetic anomalies 25 to 34.

Over much of the cored interval on which paleomagnetic studies were run, core recovery was variable, averaging $57 \%$. The stratigraphic gaps limit the usefulness of Hole 530A results for defining detailed Cretaceous reversal sequences particularly within the Maestrichtian interval. The reversal stratigraphy proved very useful, however, where Cretaceous strata were barren or contained long-ranging microfossils which yielded little biostratigraphic control.

\section{Cenozoic}

There is good fossil control on the Cenozoic sediments of Hole 530A. Five normal polarity epochs (anomalies 25 through 29) are identified within Cores 40 through 50 (Fig. 2). Just above the Cretaceous/Tertiary boundary in Core 50, significant reworking of Cretaceous species is evident. The boundary, as identified by calcareous nannofossils, lies within $10 \mathrm{~cm}$ of the polarity change at the end of the Cretaceous.

\section{Cretaceous}

The Maestrichtian (Cores 50 to 59 ) is characterized by mixed polarity, whereas the Campanian (Cores 60 to 80 ) is dominantly normal with reversed polarity zones being present only near the upper and lower boundaries. These results are compatible with those of Keating et al. (1975a) and Keating and Helsley (1979). The upper Campanian reversed polarity is an extension of the Maestrichtian mixed polarity sequence. The two reversals found near the Campanian/Santonian boundary are probably the same as those reported by Keating et al. (1975b).

The interval from Core 68 to 80 contains abundant turbidite sequences. Turbidites in general are not ideal candidates for magnetostratigraphy because they represent episodic and catastrophic movements of sediment down slope from their original site of deposition. Moreover, the coarse sandstones within the turbidite units tend to be magnetically unstable due to the larger magnetic grain size. The interval is marked by two reversed polarity intervals separated by a brief normal polarity interval. This polarity sequence has been identified elsewhere in deep-sea sediment cores of early Campanian age. Thus, despite the nature of its deposition, the turbidite appears to be magnetized systematically in the true paleofield direction. The only correction necessary is for the anomaly in sedimentation rate produced by the presence of turbidite deposition.

The Santonian through Cenomanian interval (Cores 81 through 103) is characterized by normal polarity. This is correlated with the Late Cretaceous Quiet Interval. This is consistent with observations by Keating (1976) and Helsley and Steiner (1969), as well as those from DSDP Legs 40 through 44 , with the exception of a few reversed samples occurring near the Turonian/Cenomanian boundary at Site 361 (Keating and Helsley, 1978). No evidence of this magnetic reversal is preserved at Hole 530A.

Studies on pre-Cenomanian sediments have shown that they are characterized by mixed polarity throughout the lower Cretaceous and first encountered near the Cenomanian/Albian boundary (Helsley and Steiner, 1969; Irving and Couillard, 1973; Lowrie et al., 1980). The results from Hole 530A suggest that no Early Cretaceous sediments of mixed polarity are present. Hence, 
magnetostratigraphy indicates that the age of the sediments at the base of Hole 530A are no older than latest Albian. This is in agreement with the calcareous nannofossil biostratigraphy on Hole 530A sediments (Stradner and Steinmetz, this volume).

\section{REFERENCES}

Barron, E. J., and Harrison, C. G. A., 1980. An analysis of past plate motions: The South Atlantic and Indian oceans. In Davies, P. A., and Runcorn, S. K. (Eds.), Mechanisms of Continental Drift and Plate Tectonics: London (Academic Press), pp. 89-109.

Barron, E. J., Harrison, C. G. A., Sloan, J. L., II, and Hay, W. W., 1981. Paleogeography, 180 million years ago to present. Eclog. Geol. Helvetae, 74:443-470.

Barron, J. A., Poore, R. Z., and Wolfart, R., 1981. Biostratigraphic summary. Deep Sea Drilling Project Leg 63. In Yeats, R. S., Haq, B. U., et al., Init. Repts. DSDP, 63: Washington (U.S. Govt. Printing Office), 927-941.

Berggren, W. A., 1973. The Pliocene time scale: Calibration of planktonic foraminiferal and calcareous nannoplankton zones. Nature, 243:391-397.

Bukry, D., 1973. Coccolith stratigraphy, Eastern Equatorial Pacific, Leg 16, Deep Sea Drilling Project. In van Andel, Tj. H., Heath, G. R., et al., Init. Repts. DSDP, 16: Washington (U.S. Govt. Printing Office), 653-712.

1975. Coccolith and silicoflagellate stratigraphy, northwestern Pacific Ocean, Deep Sea Drilling Project Leg 32. In Larson, R. L., Moberly, R., et al., Init. Repts. DSDP, 32: Washington (U.S. Govt. Printing Office), 677-701.

Burckle, L. H., 1977. Pliocene and Pleistocene diatom datum levels from the equatorial Pacific. Quat. Res., 7:330-340.

Ellis, C. H., 1979. Neogene nannoplankton zonation in eastern Mediterranean. Proc. 7th Intl. Cong. Medit. Neogene (Tome hors serie), 1:391-401.

1982. Calcareous nannoplankton biostratigraphy-Deep Sea Drilling Project Leg 60. In Hussong, D. M., Uyeda, S., et al., Init. Repts. DSDP, 60: Washington (U.S. Govt. Printing Office), 507-535.

Hay, W. W., Sibuet, J.-C., and the Leg 75 Scientific Party, 1982. Sedimentation and accumulation of organic carbon in the Angola Basin and on Walvis Ridge: Preliminary results of Deep Sea Drilling Project Leg 75. Geol. Soc. Am. Bull., 93(10):1038-1050.

Helsley, C. E., and Steiner, M. B., 1969. Evidence for long intervals of normal polarity during the Cretaceous period. Earth Planet. Sci. Lett., 5:325-332.

Irving, E., and Couillard, G. W., 1973. Cretaceous normal polarity interval. Nature, 244(131):10-11.

Jenkins, D. G., 1978. Neogene planktonic foraminifers from DSDP Leg 40, Sites 360 and 362 in the southeastern Atlantic. In Bolli, H. M., Ryan, W. B. F., et al., Init. Repts. DSDP, 40: Washington (U.S. Govt. Printing Office), 723-741.

Keating, B., 1976. Contribution to paleomagnetism [Ph.D. dissert.]. University of Texas at Dallas, Dallas.
Keating, B., and Helsley, C. E., 1978. Magnetostratigraphy of Cretaceous age sediments from Sites 361, 363, 364, and 365. In Bolli, $\mathrm{H}$. M., Ryan, W. B. F., et al., Init. Repts. DSDP, 40: Washington (U.S. Govt. Printing Office), 459-467.

1979. Magnetostratigraphy of Cretaceous sediments from DSDP Site 386. In Tucholke, B. E., Vogt, P. R., et al., Init. Repts. DSDP, 43: Washington (U.S. Govt. Printing Office), 781-784.

Keating, B., Helsley, C. E., and Pessagno, E. A., Jr., 1975a. Late Cretaceous reversal sequence. Geology, 3:73-76.

1975b. Reversed events within the Late Cretaceous normal polarity interval. EOS, Trans. Am. Geophys. Union, 56:354.

Kennett, J. P., 1973. Middle and late Cenozoic planktonic foraminiferal biostratigraphy of the southwest Pacific-DSDP Leg 21. In Burns, R. E., Andrews, J. E., et al., Init. Repts. DSDP, 21: Washington (U.S. Govt. Printing Office), 575-639.

Koizumi, I., 1977. Diatom biostratigraphy in the North Pacific region. Proc. First Intl. Congr. Pac. Neogene Stratig., Tokyo, 1976, pp. 235-253.

Lowrie, W., Alvarez, W., Premoli Silva, I., and Monechi, S., 1980. Lower Cretaceous magnetic stratigraphy in Umbrian pelagic carbonate rocks. Geophys. J. Roy. Astron. Soc., 60:263-281.

Martini, E., 1971. Standard Tertiary and Quaternary calcareous nannoplankton zonation. In Farinacci, A. (Ed.), Proc. Sec. Plankt. Conf. (Tecnoscienza, Roma), 2:739-785.

Maxwell, A. E., Von Herzen, R. P., and Shipboard Scientific Party, 1970. Site 21. In Maxwell, A. E., Von Herzen, R. P., et al., Init. Repts. DSDP, 3: Washington (U.S. Govt. Printing Office), pp. $367-411$.

Okada, H., and Bukry, D., 1980. Supplementary modification and introduction of code numbers to the low-latitude coccolith biostratigraphic zonation (Bukry, 1973; 1975). Mar. Micropaleontol., 5: 321-325.

Pflaumann, U., and Čepek, P., 1982. Cretaceous foraminiferal and nannoplankton biostratigraphy and paleoecology along the West African continental margin. In von Rad, U., Hinz, K., Sarnthein, M., and Seibold, E. (Eds.), Geology of the Northwest African Continental Margin: Berlin, Heidelberg, New York (Springer-Verlag), pp. 309-353.

Sancetta, C., 1982. Diatom biostratigraphy and paleoceanography, Deep Sea Drilling Project Leg 68. In Prell, W. L., Gardner, J. V., et al., Init. Repts. DSDP, 68: Washington (U.S. Govt. Printing Office), pp. 301-309.

Srinivasan, M. S., and Kennett, J. P., in press. Neogene planktonic foraminiferal biostratigraphy and evolution: Equatorial to subantarctic, South Pacific. Mar. Micropaleontol.

Thiede, J., and Dinkelman, M. G., 1977. Occurrence of Inoceramus remains in late Mesozoic pelagic and hemipelagic sediments. In Supko, P. R., Perch-Nielsen, K., et al., Init. Repts. DSDP, 39: Washington (U.S. Govt. Printing Office), pp. 899-910.

Weiss, R. F., 1970. The solubility of nitrogen, oxygen and argon in water and seawater. Deep-Sea Res., 17:721-735.

Date of Initial Receipt: January 5, 1982 